\title{
ASSOCIATION BETWEEN SELF CONTROL AND PREMARITAL SEXUAL BEHAVIOR IN JUNIOR HIGH SCHOOL STUDENTS NEAR LOCALIZATION AREA
}

\author{
Nindita Arum Veibiani'), Anisa Catur Wijayanti²), Izzatul Arifah²) \\ 1)Masters Program in Public Health, Universitas Sebelas Maret \\ 2)Study Program of Public Health, Faculty of Health Sciences, \\ Universitas Muhammadiyah Surakarta
}

\begin{abstract}
Background: The sexual behavior of adolescents is one of the health priorities of society because of a high prevalence of HIV/AIDS, sexually transmitted infections (STIs), and unwanted pregnancies. Recently, low self-control has been associated with early sexual initiation and with risky sexual behaviors. The purpose of this study was to examine the association between self-control and premarital sexual behavior in junior high school students near localization area.

Subjects and Method: A cross sectional study was conducted at Junior High Schools that located near localization area in Semarang, Central Java, Indonesia. The study population was junior highs school students. A number of 264 students was selected for this study by cluster random sampling. The dependent variable was premarital sexual behavior. The independent variable was self-control. The data were collected by questionnaire and analyzed by Chi square test.

Results: Lower self control increasds the risk premarital sexual behavior in adolescents and it was statistically significant $(\mathrm{OR}=0.26 ; 95 \% \mathrm{CI}=0.15$ to $0.44 ; \mathrm{p}<0.001)$.

Conclusion: Lower self control increases the risk premarital sexual behavior in adolescents.
\end{abstract}

Keywords: self control, premarital sexual behavior, adolescents

\section{Corespondence:}

Nindita Arum Veibiani. Masters Program in Public Health, Universitas Sebelas Maret. Jl. Ir. Sutami 36A, Surakarta 57126, Central Java. Email: nindita.veibiani@gmail.com. Mobile: +6285800216969 . 